\title{
Serum zinc levels in diabetic patients with and without dyslipidaemia and cardiovascular diseases
}

\author{
Lakmal Jayaweera $^{1 \& 2}$, Mohamed Shafras ${ }^{2}$, Ayanthi Navaratne ${ }^{3}$, Mohamed Sanas $^{2}$, Charles Antonypillai ${ }^{2}$ \\ ${ }^{1}$ Postgraduate Institute of Science, University of Peradeniya, Peradeniya, Sri Lanka \\ 2 Department of Diabetes and Endocrionology, National Hospital, Kandy, Sri Lanka \\ ${ }^{3}$ Department of Chemistry, University of Peradeniya, Peradeniya, Sri Lanka
}

Abstract

Introduction: Diabetes mellitus (DM) is a major health problem which increases the risk of cardiovascular diseases (CVDs). Zinc $(\mathrm{Zn})$ has a number of antioxidant functions which neutralize the reactive oxygen species (ROS) generated in patients with diabetes. ROS stimulate oxidation of low density lipoprotein (LDL), cholesterol, cholesterol derived species in atherosclerotic plaques in arteries in dyslipidaemia patients. The oxidized LDL (Ox-LDL) has been identified as a major cause of endothelial dysfunction leading to CVDs.

Objective: In this study, the serum $\mathrm{Zn}$ levels, anthropometric and clinical parameters of diabetes patients with and without dyslipidaemia and CVDs were investigated.

Method: The serum samples of 116 subjects which include 42 patients with Type 2 Diabetes Mellitus (T2DM) alone, 55 patients with T2DM and dyslipidaemia and 19 patients with T2DM, dyslipidaemia and CVD from diabetes and endocrinology clinic were analysed.

Results: The serum Zn levels of diabetes patients $(944.69 \pm 241.53 \mathrm{ppb})$, diabetes with dyslipidaemia $(991.45 \pm 265.50 \mathrm{ppb})$ and diabetes, dyslipidaemia and CVD $(1,000.97 \pm 295.17 \mathrm{ppb})$ were not statistically significant \{significance value of the ANOVA test was $0.619(\mathrm{p}=0.619>\alpha=0.05)\}$. Zinc deficiency was $27.27 \%$ among male patients and $16.00 \%$ among female patients. Zinc concentration among Type 2 diabetes patients was not affected by, gender, body mass index (BMI) and duration of diabetes.

Conclusion: Serum zinc levels were not statistically different among diabetic patients with and without dyslipidaemia and CVD. The role of serum zinc levels in T2DM and CVDs need to be examined further in long term longitudinal trials. (SJDEM 2020/Vol 10/No 2)

Keywords: Diabetes Mellitus, Cardiovascular diseases, Serum Zn, ROS, oxidized LDL.

Correspondence email: way2shafraz@gmail.com

ORCID ID: https://orcid.org/ 0000-0002-4827-0275

Copyright: This is an open-access article distributed under the terms of the Creative Commons Attribution License, which permits unrestricted use, distribution, and reproduction in any medium, provided the original author and source are credited (CC BY 4.0) 
Atherosclerotic cardiovascular disease is a leading cause of death with estimated $31 \%$ of all deaths worldwide (1). Diabetes mellitus (DM) and dyslipidaemia are some of the main risk factors for it. In DM, increased plasma glucose in turn causes the generation of ROS and the excess generation of ROS causes oxidative stress, which further develops the progression of diabetes and its complications. Oxidative stress is currently the unifying factor in the development of diabetes complications (2).With the development of diabetes, oxidation of lipids, proteins and deoxyribonucleic acid (DNA) increase with time. Recent research shows oxidative stress is a primary or secondary cause of many CVDs (3). Further in vivo and ex vivo studies have provided evidence supporting the role of oxidative stress in a number of CVDs such as atherosclerosis, ischemia, hypertension, cardiomyopathy, cardiac hypertrophy and congestive heart failure (4). Further, pancreatic $\beta$-cells are particularly sensitive to oxidative damage by free radicals ${ }^{(5)}$. In a study conducted by Sarita \& Afreen showed that increased production of free radicals is an important trigger for insulin resistance (6).

ROS and other free radicals are detoxified by natural antioxidant mechanisms such as glutathione, catalase, superoxide dismutase (SOD) and more recently described metallothionein (MT) (7\&8). Superoxide radicals are reduced to hydrogen peroxide by SOD in the presence of copper and zinc cofactors ${ }^{(9)}$. Zinc is second to iron as the most abundant trace element in the body. Zinc ions exist primarily in the form of complexes with proteins and nucleic acids and participate in all aspects of intermediary metabolism, transmission and regulation of the expression of genetic information, storage, synthesis and action of peptide hormones and structural maintenance of chromatin and biomembranes. Zinc is an essential cofactor in a variety of enzymes. It can stabilize macromolecules against radical-induced oxidation in vitro as well as limit excess radical production (10). Zinc also plays an important role in the synthesis and function of insulin, it is capable of modulating insulin action, and it improves hepatic binding of insulin ${ }^{(11)}$. Most of the complications of diabetes may be related to increased intracellular oxidants and free radicals associated with a decrease in intracellular zinc and zinc dependent antioxidant enzymes ${ }^{(12)}$.

In non-diabetic subjects, serum $\mathrm{Zn}$ is associated with increased incidence of CVDs (13). However, the enhanced risk of CVDs of T2DM patients is not completely explained by traditional risk factors (14\&15). Previous studies have shown that serum zinc level is lower in diabetic patients than in non-diabetic subjects, increased urinary zinc excretion being the main reason (16-19). In another study $\mathrm{Zn}$ deficiency was found to be a risk factor for cardiac oxidative damage and supplementation with $\mathrm{Zn}$ provides.
Significant prevention of oxidative damage to the heart (20). Further, there is very little information on the zinc status of populations worldwide due to the lack of appropriate biochemical indicators of $\mathrm{Zn}$ status. So, serum $\mathrm{Zn}$ content is not usually analyzed as an investigation in routine clinical practices. Therefore, sufficient information is not available for zinc levels for patients with T2DM, patients with T2DM with dyslipidaemia and patients with T2DM with dyslipidaemia and CVDs. Hence this study was carried out to investigate the serum $\mathrm{Zn}$ levels of patients with T2DM, patients with T2DM with dyslipidaemia and patients with T2DM with dyslipidaemia and CVDs and to determine whether there are any similarities among the serum $\mathrm{Zn}$ levels of the above groups.

\section{Methodology}

This is a cross sectional study conducted among subjects attending to diabetes clinic National Hospital Kandy, Sri Lanka. The study was carried out from 16 Nov 2016 to 30 March 2017. All the protocols used were in accordance with the guidelines for the protection of human subjects. Patients with T2DM, T2DM with dyslipidaemia and T2DM with dyslipidaemia and recent CVDs were recruited for the study. Patients with Inflammatory bowel disease including Crohn's disease, ulcerative colitis, cancers, renal failure, thyroid dysfunction, liver disease, human immunodeficiency virus (HIV), strict vegetarians \& patients who are on any treatment with $\mathrm{Zn}$ or drugs affecting $\mathrm{Zn}$ level in the four weeks prior to enrolment were excluded from the study. The selected patients were categorized into 3 groups namely group A, B and C. The group A contained patients with only T2DM. American Diabetes Association guidelines were used for diagnosis of diabetes (21). This group subjects were considered as the control group. The group B contained patients with T2DM \& dyslipidaemia. The group B subjects had LDL cholesterol (LDL-C) values above $100 \mathrm{mg} / \mathrm{dL}$. The group C contained patients with T2DM, dyslipidaemia and prior history of cardiovascular event. CVD was defined as presence of history of previous myocardial infarction, coronary artery bypass surgery, positive stress testing, stenosis $>50 \%$ at one or more coronary arteries \& ischaemic stroke. The LDL-C values of the patients of this group were also more than $100 \mathrm{mg} / \mathrm{dL}$. In this study none of the participants were on a special diet. There were no any cigarette smokers or alcoholics. The serum samples were digested by Ethos Easy -Milestone microwave digestion system and serum $\mathrm{Zn}$ concentrations were determined by Microwave Plasma Atomic Emission Spectrometer (Agilent 4200 MP-AES).

\section{Results and Discussion}

In this study, there were 116 subjects (50 women and 66 men). Mean age was $51.78 \pm 8.84$ years for female patients (range 2769 years) and $53.39 \pm 8.99$ for male patients (range 32- 78 years). Baseline patient characteristics are shown in Table 1. 


\begin{tabular}{cccc}
\hline Male/Female (\%) & $62 / 38$ & $49 / 51$ & $68 / 32$ \\
Age(Years) & $47.57 \pm 8.05$ & $54.16 \pm 7.91$ & $59.8 \pm 7.29$ \\
$\begin{array}{c}\text { Body Mass Index } \\
\text { (kg/m2) }\end{array}$ & $24.34 \pm 3.26$ & $24.39 \pm 3.71$ & $24.55 \pm 2.59$ \\
$\begin{array}{c}\text { Duration of diabetes } \\
\text { (Years) }\end{array}$ & 8.6 & 7.7 & 21.78 \\
Hypertension (Yes \%) & $76.19 \%$ & $41.81 \%$ & $100 \%$ \\
Insulin (yes \%) & $9.52 \%$ & $25.45 \%$ & $31.57 \%$ \\
\hline
\end{tabular}

Serum zinc levels among three groups of patients

There were no any differences in the serum zinc levels among three groups of patients \{the significance value of the ANOVA test was $0.619(\mathrm{p}=0.619>\alpha=0.05)\}$. The mean serum zinc level was also lower in patients with only diabetes
(944.69 \pm 241.53$)$ compared to the other two groups (Table 2). Several studies showed that heart failure patients had lower serum zinc level(22-24) while others claims that there is no any significant difference in the serum zinc among heart failure subjects and control group (25\&26).

\section{Table 2: Mean serum levels of the three groups}

\begin{tabular}{ccccccc}
\hline & $\mathbf{n}$ & $\begin{array}{c}\text { Serum Zinc } \\
(\mathbf{p p b}) \\
\text { Mean } \pm \text { SD }\end{array}$ & \multicolumn{2}{c}{$\begin{array}{c}\mathbf{9 5 \%} \text { Confidence Interval } \\
\text { for Mean }\end{array}$} & Minimum & Maximum \\
& & Lower & Upper & & \\
Bound & Bound & & \\
$\begin{array}{c}\text { DM + } \\
\text { Dyslipidaemia } \\
\text { DM }\end{array}$ & 55 & $991.45 \pm 265.50$ & 919.67 & $1,063.23$ & 500.00 & $1,549.00$ \\
& 42 & $944.69 \pm 241.53$ & 869.42 & $1,019.95$ & 421.00 & $1,432.00$ \\
$\mathbf{D M}+\mathbf{C V D}$ & 19 & $1,000.97 \pm 295.17$ & 858.71 & $1,143.24$ & 542.00 & $1,575.00$ \\
& & & & & & \\
\hline
\end{tabular}


As per the Pearson correlation analysis, there was no any association with age, gender, BMI and duration of diabetes and serum zinc concentration. The study conducted by Masood N et al also showed that there was no association between age, gender, BMI and the duration of diabetes on the serum zinc concentration in type- 2 diabetic patients ${ }^{(17)}$. Analysis of serum zinc levels in patients with and without hypertension showed that the mean serum zinc levels in diabetes patients with hypertension $(1022.5 \pm 277.4)$ were higher than the patients without hypertension $(942.5 \pm 242.2)$ irrespective of gender. Analysis of serum zinc levels in patients with and without insulin treatment showed that the mean serum zinc level was similar in insulin-treated subjects $(992.70 \pm 250.78)$ and who did not have insulin included in their treatment (910.22 \pm
307.41). Moreover, mean serum zinc level was not different among female $(976.6 \pm 249.8 \mathrm{ppb})$ and the male $(975.7 \pm 271.0 \mathrm{ppb})$ patients. Similar results were seen in a study done by Chooi et al. (27).

Evaluation of serum zinc levels and possible biological conditions showed that $22.41 \%$ of the total population had zinc deficiency due to physiological fluctuations. A higher percentage of zinc deficiency due to physiological fluctuation was found in male patients $(27.27 \%)$ than female patients $(16.00 \%)$. However, the prevalence of $\mathrm{Zn}$ deficiency was similar among female $(8.00 \%)$ and male $(7.57 \%)$ patients.

Table 3: Possible conditions and the population based zinc levels

\begin{tabular}{|c|c|c|c|c|}
\hline $\begin{array}{lccr}\text { Serum } & \text { zinc } & \text { level } \quad \mathrm{ppb}=\mu \mathrm{g} / \mathrm{dm} 3 \\
& & \\
\text { (parts } & \text { per } & \text { billion) } & \text { Possible } \\
\text { conditions } & & \end{array}$ & DM & $\begin{array}{l}\text { DM + } \\
\text { Dyslipidaemia }\end{array}$ & $\begin{array}{l}\text { DM+ } \\
\text { Dyslipidaemia } \\
+ \text { CVD }\end{array}$ & Total population \\
\hline $3000-7000$ & 0 & 0 & 0 & 0 \\
\hline Acute $\mathrm{Zn}$ intoxication (reported) & & & & \\
\hline $1600-2990$ & 0 & 0 & 0 & 0 \\
\hline $\begin{array}{l}\text { Intoxication or secondary elevation } \\
\text { due to excessive intake or } \\
\text { hemodialysis }\end{array}$ & & & & \\
\hline $840-1590$ & $29(69.04 \%)$ & $39(70.91 \%)$ & $13(68.42 \%)$ & $81(69.8 \%)$ \\
\hline Normal range & & & & \\
\hline $600-830$ & $10(23.80 \%)$ & $11(20.00 \%)$ & $5(26.31 \%)$ & $26(22.41 \%)$ \\
\hline $\begin{array}{l}\text { Zinc Deficiency Physiological } \\
\text { fluctuation variation caused by } \\
\text { drugs, etc }\end{array}$ & & & & \\
\hline Below 590 & $3(7.14 \%)$ & $5(9.09 \%)$ & $1(5.26 \%)$ & $9(7.75 \%)$ \\
\hline Deficiency & & & & \\
\hline
\end{tabular}


Evaluation of serum zinc levels and possible biological conditions showed that majority of female $(76.00 \%)$ and male $(65.15 \%)$ patients were within the normal range. This result was similar to the results showed by Yanagisawa (28). As per the reference ranges for zinc in human serum published by Yanagisawa, none of the patients had the serum zinc levels higher than the upper limit of normal range(28).

\section{Conclusions and Recommendations.}

There were no difference in the mean serum zinc levels between diabetic subjects with and without dyslipidaemia and CVDs. Age, gender, BMI and duration of diabetes does not affect on the serum zinc concentration in type-2 diabetic patients. The role of serum zinc levels in T2DM and CVDs, factors predisposing zinc deficiency need to be examined further in long term longitudinal trials.

\section{Funding}

This research did not receive any specific grant from any funding agency in the public, commercial or not-for-profit sector.

\section{Conflict of interest:}

The authors declare that they have no conflict of interest.

\section{Limitations of the study}

This is not a longitudinal study to study causation and the sample size is small. 


\section{References}

1. World Health Organization. Cardiovascular diseases (CVDs) Fact sheet. 2017, cited 20 Nov 2017. Available from http://www.who.int/mediacentre/factsheets/fs317/en/

2. Asmat U, Abad K, Ismail K. Diabetes mellitus and oxidative stress-A concise review. Saudi Pharm. J. 2016; 24:547-553. DOI: $10.1016 /$ j.jsps.2015.03.013.

3. Ceriello A. Possible role of oxidative stress in the pathogenesis of hypertension. Review. Diabetes Care. 2008; 31(2):S181184.

4. Bing L, Shujun L, Lining M,Lu C. Prevention of Diabetic Complications by Activation of Nrf2: Diabetic Cardiomyopathy and Nephropathy. J. Diabetes Res. 2012; Article ID 216512, 7 pages. doi:10.1155/2012/216512

5. Sen S, Chakraborty R, De B. Diabetes Mellitus in 21st Century. 2016. ISBN 97898110154109789811015427 (online). Springer Singapore. doi:10.1007/978-981-10-1542-7

6. Sarita B,Afreen K. Antioxidants and diabetes. Indian J EndocrinolMetab. 2012; 1(2): S267-S271. doi: 10.4103/22308210.104057

7. Maqsood ME, Kong YX, Bashir M.M. Oxidative stress as a mediator of cardiovascular disease. Oxid Med Cell Longev.2009; 2(5):259-269. https://www.ncbi.nlm.nih.gov/pmc/articles/PMC2835914/.

8. Veena D. Reactive Oxygen and Nitrogen Species: General Considerations in Studies on Respiratory Disorders. In Ganguly NK, Jindal SK, Biswal S, Barnes PJ, Pawankar R, editors. Oxidative Stress in Applied Basic Research and Clinical Practice. Springer New York Heidelberg Dordrecht London; 2014. P.27 -47. DOI: 10.1007/978-1-4939-0497-6_2.

9. Ghodaro OM, Akinloye OA. First line defence antioxidants-superoxide dismutase (SOD), catalase (CAT) and glutathione peroxidase (GPX): Their fundamental role in the entire antioxidant defence grid. Alexandria J. Med. 2017; 54(4): $287-293$. DOI: 10.1016/j.ajme.2017.09.001.

10. Nazanin R, Richard H, Roya K, Rainer S. Zinc and its importance for human health: An integrative review. $J$ Res Med Sci.2013; 18(2):144-157. https://www.ncbi.nlm.nih.gov/pmc/articles/PMC3724376/

11. Neyab R, Saeeb AN. Minerals and lipid profiles in cardiovascular disorders in Asia. 2014. Springer-Verlag Berlin Heidelberg 2014. DOI 10.1007/978-3-642-34249-3

12. Chausmer AB. Zinc, insulin and diabetes. J Am Coll Nutr.2008; 17(2):109-15. https://www.ncbi.nlm.nih.gov/pubmed/9550453

13. Soinio M, Marniemi J, Laakso M, Pyörälä K, Lehto S, Rönnemaa T. Serum zinc level and coronary heart disease events in patients with type 2 diabetes. Diabetes Care. 2007;30(3):523-528

14. Martín-Timón I, Sevillano-Collantes C, Segura-Galindo A, Del Cañizo-Gómez FJ. Type 2 diabetes and cardiovascular disease: have all risk factors the same strength?. World J Diabetes. 2014;5:444-470. https://www.ncbi.nlm.nih.gov/pmc/articles/PMC4127581/

15. Adrià A. Cardiovascular risk factors for acute stroke: Risk profiles in the different subtypes of ischemic stroke. World J Clin Cases. 2015; 3(5): 418-429. DOI: 10.12998/wjcc.v3.i5.418 
16. Al-Maroof RA, Al-Sharbatti SS. Serum zinc levels in diabetic patients and effect of zinc supplementation on glycemic control of type 2 diabetics. Saudi MedJ. 2006;27(3):344-50. https://www.ncbi.nlm.nih.gov/pubmed/16532095

17. Masood N, Baloch GH, Ghori RA, Memon IA, Memon MA, Memon MS. Serum zinc and magnesium in type-2 diabetic patients. J Coll Physicians Surg Pak. 2009; 19:483-486.

http://applications.emro.who.int/imemrf/jcpsp/jcpsp_2009_19_8_483.pdf

18. Gunasekara P, Hettiarachchi M, Liyanage C, Lekamwasam S. Effects of zinc and multimineral vitamin supplementation on glycemic and lipid control in adult diabetes. Diabetes Metab Syndr Obes. 2011;4:53-60. https://www.ncbi.nlm.nih.gov/pmc/articles/PMC3064411/

19. Praveena S, Sujatha P, Praasula KSP. Trace elements in diabetes mellitus. J Clin Diagn Res. 2013;7:18631865.https://www.ncbi.nlm.nih.gov/pmc/articles/PMC3809622/

20. Song Y, Wang J, Li X, Cai L. Zinc and the Diabetic Heart. Biometals. 2005; 18(4):325-32. https://doi.org/10.1007/s10534005-3689-7

21. American Diabetes Association. Standards of Medical Care in Diabetes-2011. Diabetes Care. 2011; 34(1): S11S61.https://doi.org/10.2337/dc11-S011.

22. Kosar F, Sahin I, Taskapan C, Kucukbay Z, Gullu H, Taskapan H. Trace element status (Se, Zn, Cu) in heart failure. Anadolu Kardiyol Derg. 2006; 6:216-220.

23. Ghaemian A, Salehifar E, Jalalian R, Ghasemi F, Azizi S, Masoumi S, et al. Zinc and copper levels in severe heart failure and the effects of atrial fibrillation on the zinc and copper status. Biol Trace Elem Res. 2011; 143: 1239-1246.

24. Alexanian, Parissis J, Farmakis D, Athanaselis S, Pappas L, Gavrielatos G, et al. Clinical and echocardiographic correlates of serum copper and zinc in acute and chronic heart failure. Clin Res Cardiol. 2014; 103(11): 938-949.

25. Salehifar E, Shokrzadeh M, Ghaemian A, Aliakbari S, Saravi S. The study of Cu and Zn serum levels in idiopathic dilated cardiomyopathy (IDCMP) patients and its comparison with healthy volunteers. Biol Trace Elem Res. 2008; 125(2): 97-108.

26. Shokrzadeh M, Ghaemian A, Salehifar E, Aliakbari S, Saravi S, Ebrahimi P. Serum zinc and copper levels in ischemic cardiomyopathy. Biol Trace Elem Res. 2009; 127:116-123.

27. Chooi MK, Todd JK, Boyd ND. Influence of age and sex on plasma zinc levels in normal and diabetic individuals. Nutr Metab. 1976;20(2):135-42. https://www.ncbi.nlm.nih.gov/pubmed/958654

28. Hiroyuki Y. Zinc Deficiency and Clinical Practice. JMAJ. 2004; 47(8):359-364. http://www.med.or.jp/english/pdf/2004_08/359_364.pdf 